\title{
COLONIAL MILITARY INTELLIGENCE IN THE ZULU REBELLION, 1906
}

\author{
PS Thompson \\ University of KwaZulu-Natal
}

Abstract

In the Zulu Rebellion of 1906, the Natal Militia defeated the Zulu rebels without British imperial forces having to intervene in the conflict. The colonial forces were well adapted to the local circumstances, but in one important respect they drew heavily on imperial experience, namely military field intelligence. Colonial military intelligence was modelled on imperial military intelligence in the South African War (1899-1902). The Natal Militia, reorganised in 1903, lacked an intelligence department at the outbreak of the rebellion, and had to improvise a system quickly. The improvisation in the field proved very effective, providing valuable information on the enemy's strength, dispositions and intentions, and so contributed to the timely victory of the colonial forces at the battle of Mome (10 June 1906). This article gives the imperial background and describes the organisation (staff, officers and operatives, scouts and spies) and operations (collection, interpretation and dissemination of information) of colonial military intelligence in the field during the crucial second phase of the rebellion.

\section{Introduction}

The Zulu Rebellion of 1906 provides a classic example of secondary resistance to European colonisation in southern Africa. It is also one of those "small wars of empire", which Imperial (or in this case, colonial) forces usually won against indigenous ones, because of superior organisation and technology. A factor in colonial success reflecting this superiority is intelligence, i.e. the organised and systematic collection, analysis, and interpretation of information about the enemy and the application of this knowledge to contribute to victory over him. Ideally, intelligence plays a significant part in military planning and operations, and

Scientia Militaria, South African Journal of Military Studies, Vol 42, Nr 1, 2014, pp. 18-43. doi : $10.5787 / 42-1-1079$ therefore is a significant factor in the issue of operations.

In the case of the Zulu Rebellion of 1906, just enough documentation of military 
intelligence has survived to allow a reconstruction of its organisation and operation, and it is the purpose of this article to describe the colonial militia's intelligence service during the rebellion, focussing on operations in Zululand in the second phase or so-called 'Bhambatha Rebellion'. The thesis of the article is that the rebellion forced the Natal Militia to establish an intelligence department and to improvise a system of field intelligence specially adapted to the situation, which it did with remarkable success.

Natal suffered invasion during the South African War (1899-1902), although the war stimulated the economy and added more territory to the province in its aftermath. Peace brought economic depression and social agitation. ${ }^{1}$ Natal had become a self-governing colony in 1893, and as such was expected to provide for its own defence. The South African War was exceptional because of its magnitude and scope, but after the war, the Colony had to rely more on its own than on Imperial resources for defence. The Militia Act of 1903 reorganised the militia, but financial constraints held back implementation of the programme. ${ }^{2}$

In 1905 , the colonial government enacted a capitation of $£ 1$ on adult males, which fell most heavily on black Africans. When the tax became payable in January 1906, there were several violent demonstrations. On 9 February, a fracas in southern Natal led to martial law and mobilisation of the militia. The ensuing Zulu Rebellion of 1906 was brief and bloody and, of course, ended in the rebels' defeat. The rebellion comprised three phases. The first phase, in February and March, consisted of a military demonstration in the south to overawe disaffected chiefdoms. The second phase began in April with the rebellion of a petty Natal chief Bhambatha. ${ }^{3}$ The colonial government dismissed him for misconduct and he went to the former Zulu king Dinuzulu for help. He consequently returned to Natal and attacked the authorities, more to regain his chieftaincy than to contest the poll tax. Colonial forces gathered against him, and he fled to Zululand again, and allied with the influential chiefs Sigananda in Nkandla and Mehlokazulu in Nquthu. The situation was critical, and the government used Natal militia and units from the Cape Colony and the Transvaal to suppress the unrest. Victory was achieved at the battle of the Mome Gorge on 10 June 1906. The third phase of the rebellion, June-July, comprised a futile uprising in the Maphumulo district of Natal. ${ }^{4}$

\section{Field intelligence after the South African War}

During the South African War (1899-1902), the British army's military intelligence department expanded significantly. At the end of 1901, the Field Intelligence Department included 132 officers, 2321 Europeans and an estimated thousands of natives. ${ }^{5}$ The experience of these men and the army's interpretation and 
publication of the lessons of field intelligence were to have an important effect on colonial military thinking as well.

Before and during the war, the army's manual was Sir Garnet Wolseley's The soldier's pocket book for field services. The 1885 edition dealt with collecting, processing, analysing and disseminating information by a field intelligence department as such and by mounted units, individual soldiers in the field, spies and informers behind the enemy lines, and even by civilians when there were not enough soldiers to do the job. Reconnaissance by mounted units was considered the most reliable method of collecting information, but the manual dealt with the interception of enemy messages, the interrogation of prisoners and deserters, the employment of spies and local informers. There was even something on the use of balloons!

In April 1904, the manual was replaced by Lieutenant Colonel David Henderson's Field intelligence, its principles and practices, published by the General Staff. It incorporated the experience of the South African War, and became the textbook for intelligence officers up to the time of the Great War. Chapters covered organisation and personnel, analysis and report, guides and counterintelligence. The collection of information was covered by three chapters, covering reconnaissance, interrogation, and secret service. All persons regularly involved in intelligence work, except staff officers and secret service agents, had to be organised in an intelligence corps. In a small war, this corps would comprise a few Europeans supervising others, chiefly native guides, scouts and interpreters. The corps would be commanded by an officer who would be attached to headquarters, and who would receive instructions from the Director of Military Intelligence on the headquarters staff of the Army.

In August 1904, the General Staff published Regulations for intelligence duties in the field, which partly codified Henderson's work. Since the regulations were intended for the staff's officers attached to armies, it focussed on administration and organisation of tactical intelligence rather than the actual collection, analysis and dissemination per se. ${ }^{6}$

Colonel CE Callwell's Small wars: a tactical textbook for imperial soldiers, the third edition of which was published in 1906, contained a chapter dealing with intelligence, although it was largely descriptive and cautionary, and had relatively little in the way of practical organisation. ${ }^{7}$

There is no telling how many officers of the Natal militia read these publications. There was a militia library, and for a while, militia orders listed new titles received and encouraged officers to read them. However, the surviving list of books is very incomplete and contains no mention of the above books. ${ }^{8}$ In any case, 
by the late war, when the rebellion broke out, some officers were doubtless familiar with intelligence as practised and capable of improvising a system. ${ }^{9}$

The Natal Militia Act of 1903 marked a radical change in the Colony's defence structure. It embraced the principle of compulsory service and provided for an active militia and a reserve. The commandant of militia 1902-1905 was Colonel HP Leader, $6^{\text {th }}$ Dragoon Guards, who energetically expanded, equipped and improved the drill and training of the active militia. The government supported him generally, but the onset of economic depression led to budget cuts, and Leader rejoined his regiment in India. The governor of the Colony, Sir Henry McCallum, who was a colonel of the Royal Engineers, and the officer commanding in South Africa, Major General HJT Hildyard, wanted an Imperial officer to succeed Leader, fearing that a colonial would be too parochial and pliant with the politicians. The government got its way, and Colonel HT Bru-de-Wold, commander of the Border Mounted Rifles and district commandant in the south of the Colony, was appointed on 15 October $1905 .^{10}$

Bru-de-Wold put a premium on intelligence in view of the rebellion he was sure would erupt in about nine months' time. He set up an intelligence department at headquarters. Major RW Wilson was appointed intelligence officer. A number of officers in the three militia districts were appointed intelligence officers as well, because of their intimate knowledge of the people and the country, and they supplied headquarters with valuable information about the native population.

Bru-de-Wold also received letters from various correspondents, including police officers and magistrates, but he had reservations about Native Affairs Department sources, because they usually were persons well known in the community. It was therefore unlikely that local people, whether inclined to or not, would impart to them any political intelligence. ${ }^{11}$

General Stephenson, the British commander in the Transvaal, who came to observe operations in Zululand during the rebellion, also felt that the government had not paid sufficient attention to local Europeans as a source of information. In his opinion, the magistrates preferred to believe the reports of their court police, from whom the natives naturally concealed information of a subversive character, and rejected with contempt reports from knowledgeable locals. ${ }^{12}$

Under-Secretary for Native Affairs SO Samuelson received a continual flow of information from the resident magistrates throughout the Colony. A resident magistrate received information practically every day in the form of the reports from the native officers (izinduna) and constables attached to his court, as well as from cases tried in the court, and from time to time messages from local chiefs and others 
in their division. It was the responsibility of the under-secretary to analyse and report on such intelligence to the secretary. In addition, in 1897, the secretary for Native Affairs had introduced a system of special agents to report on unrest, because he felt that magistrates and police were inadequate for the task. Four native intelligence officers were engaged in March 1898. They criss-crossed the Colony and their reports varied in quality, and it was up to the under-secretary to sort the wheat from the chaff. ${ }^{13}$

The Natal police necessarily did intelligence work, although not of a political or military character. The Criminal Investigation Division took over cases which district stations could not readily deal with. There were twenty police districts in the Colony and, like the magistrates, the district police officers received information that might have been useful for political intelligence. ${ }^{14}$ The acting commissioner of police, WJ Clarke, gave orders to police in the rural districts to collect information from farmers and others, and to send it him directly. He knew the country and the men concerned, and was able to classify and condense the information obtained. ${ }^{15}$

Bru-de-Wold did not have access to these reports but, when there were protests against the poll tax in Natal and Zululand in January 1906, an arrangement was made with Clarke for the police and militia to cooperate in intelligence work. However, this was stopped by the chief commissioner of police, Colonel George Mansel, without explanation to the commandant. Thus, at a critical juncture, the Intelligence Department was deprived of the analytical reports of the police, and one officer at headquarters could hardly be expected to sort and assess all the reports now streaming in from outlying areas rapidly. ${ }^{16}$

\section{The improvisation of field intelligence}

That Natal militia officers had learnt the lessons of Imperial military intelligence during the South African War becomes apparent with the outbreak of the Zulu Rebellion of 1906. Militia headquarters knew what to do, and perforce became the nerve centre of an increasing network of agents, and acquired and refined intelligence from a variety of sources, as described below.

With the outbreak of the rebellion, the demands on intelligence would only have become greater. Bru-de-Wold appointed Lieutenant Colonel George Leuchars, Umvoti Mounted Rifles and a former minister for Native Affairs, as chief intelligence officer at Militia Headquarters. However, within the week, Leuchars took command of a field force in Maphumulo, and was succeeded by Lieutenant Colonel ATG Wales of Militia Staff and a former district commandant. In the latter 
part of April, Wales was ordered to northern Natal to mobilise reserves and to organise posts, and was replaced by Lieutenant Colonel Henry Lugg, also of the Umvoti Mounted Rifles and a former district commandant. ${ }^{17}$

On 10 February 1906, Bru-de-Wold appointed Lugg intelligence officer with McKenzie's Field Force, which would be operating in the south of the Colony. Lugg accompanied the column and assisted the commander in interviews with recalcitrant chiefs. He did not return to headquarters in the capital until May, and then was despatched to Zululand to investigate the murder of a magistrate. He returned to Pietermaritzburg in June, and at the behest of the Minister of Defence assembled information on Dinuzulu for an interview between the governor and the chief's emissaries. Thus, Lugg spent much of his time in the field, and made reports to headquarters, presumably per Major Wilson for the commandant. In fact, Lugg acted more like a political agent than like a military intelligence officer, and in October was made resident magistrate of the troubled Umsinga Division. ${ }^{18}$

During the South African War, the Field Intelligence Department at Army Headquarters in Pretoria issued regular "summaries" weekly and fortnightly, containing vital information for subordinate commanders. ${ }^{19}$ One of the first actions of the Intelligence Department at Militia Headquarters in 1906 was to introduce "summaries" of telegrams with vital information received from men in the field column commanders, intelligence officers on their staff (occasionally) and at certain posts (frequently), police district officers, magistrates, and some others. The system was regularised with the issuing of a "synopsis of wires received", on a daily basis from 6 April to 30 July. $^{20}$

Meanwhile, the Nkandla Division became the focal point of the rebellion in Zululand. There the rebel chiefs Bhambatha and Sigananda rallied men of various tribes to the rebel cause ostensibly in the name of Dinizulu, though publicly he disavowed them. ${ }^{21}$ The commissioner for Native Affairs in Zululand, CR Saunders, went to Empandhleni, the seat of the magistracy, and negotiated unsuccessfully for the rebels to surrender. Bru-de-Wold consulted government leaders, and ordered the Zululand Mounted Rifles and the Natal Police Field Force to Nkandla to protect the magistracy. Then he ordered the Natal Carbineers with a convoy of supplies to Empandhleni. A force of Umvoti Mounted Rifles and Reserves demonstrated along the right bank of the Tugela River to discourage Bhambatha from cutting back to Natal and tribes there joining the rebellion. A similar field force was assembled at Helpmekaar. A special service unit was raised, and units offered by the Transvaal and later the Cape Colony were gratefully accepted for service in Zululand. Natal could not cope with the rebellion on its own. 
On 23 April, the Carbineers arrived at Empandhleni, whereupon the Zululand Mounted Rifles moved west to Ntingwe and the Natal Police moved east to Fort Yolland, and so circumscribed the area of rebel operations. On 5 May, an encounter on Bhobe Ridge dispelled the rebels' belief that Bhambatha's medicine would repel the white men's bullets. Morale fell, and their élan left them. On 8 May, Colonel McKenzie arrived at Empandhleni with the new units, formed the Zululand Field Force, and prepared to take the offensive. ${ }^{22}$

The suddenness of the crisis and the distractions at headquarters left the initiation and elaboration of intelligence work by the militia field forces pretty much to the discretion of their commanders. These commanders appointed their own intelligence officers and other operatives, and headquarters acquiesced in the appointments. The intelligence officers drew on the militia units, and also recruited civilians as they were needed. During the rebellion, the Militia Intelligence Department employed, i.e. paid, 31 Europeans and 355 natives. ${ }^{23}$

Major General TE Stephenson, the officer commanding British forces in the Transvaal, was an observer with the Zululand Field Force in May and June, and reported subsequently -

Zululand has been so long in our occupation that there is no difficulty whatever in finding men who know the country thoroughly, speak the language fluently, and are well versed in the native character. These men are generally storekeepers, Surveyors, prospectors, or road Engineers. All of them have a certain number of male Natives whom they have known for years, and in whom they place implicit confidence. The Natives are sent into the various kraals to collect information and ascertain the feeling of tribes, or sections of tribes, and communicate all they hear to their Masters ...

Now Intelligence was making good use of these men -

... For work in the Field many of these agents have been employed, and the information obtained by them invaluable. For locating rebels in the bush, they have got hold of natives of the same tribes as some of the enemy, often close relations. These spies have penetrated everywhere, and constantly brought the highest intelligence of the enemy's movements and intentions. ${ }^{24}$

Much depended on the intelligence officer who made use of such men. Unfortunately, little documentation of their activity has survived. Official telegrams occasionally cited "Intelligence" with McKenzie's and Mackay's columns, but never with Leuchars' column. There is more information from his intelligence officers at 
Greytown, Helpmekaar, and Krantzkop; however, only documentation about the latter provides sufficient information to permit a reconstruction of his work, as described below.

\section{Intelligence officers in the field}

Perhaps the best-known intelligence officer is James Stuart, who wrote $A$ history of the Zulu Rebellion 1906 and of Dinuzulu's arrest, trial and expatriation (1913), which is regarded as the official account of events and the classic narrative of operations. Stuart was a civil servant of eighteen years' experience in Natal and Zululand and a magistrate in Durban when the rebellion occurred. He was also a fluent linguist and a keen scholar of the Zulu culture and history, who had already begun collecting the statements of influential and knowledgeable Zulu recently published as The James Stuart archive of recorded oral evidence relating to the history of the Zulu and neighbouring peoples in five volumes (1976-2001). ${ }^{25}$

Stuart was a captain in the Natal Field Artillery, but unattached to any particular section. Colonel Leuchars, commanding the Umvoti Field Force, employed him as intelligence officer in much the same way McKenzie did Lugg. However, when Saunders asked for men who could identify Bhambatha after he was captured, Stuart seized the opportunity to take Bhambatha's brother and several others on a daring ride through rebel-infested territory to Empandhleni. He remained there, assisting Saunders and then Colonel DW Mackay of the Carbineers, and Leuchars reluctantly let Stuart go. Following the arrival of the Zululand Field Force, Mackay returned with the Natal Carbineers to Natal. Stuart became the intelligence officer of Mackay's column, which subsequently operated in Msinga and Nquthu. ${ }^{26}$

Leuchars appointed as his intelligence officer Corporal W Norton of the Umvoti Mounted Rifles, promoting him to temporary lieutenant for the purpose. ${ }^{27}$ No mention of Norton is made in reports. Leuchars kept the Umvoti Field Force on the move, and so it was useful to have intelligence officers at fixed points, viz. Greytown and Krantzkop. Lieutenant E Fitzgerald was appointed intelligence officer at Greytown, and Captain JHM Landsberg at Krantzkop. Fitzgerald was the Inspector of Native Locations at Greytown, ${ }^{28}$ and appears to have been commissioned ad hoc. Landsberg evidently became chief intelligence officer of the Umvoti Field Force in the course of the campaign. ${ }^{29}$ Fitzgerald appears infrequently in reports, but Landsberg frequently, probably because Krantzkop was very much in the front line and Greytown was well behind it.

McKenzie had appointed Lieutenant EJB Hosking of the Natal Carbineers as an interpreter assisting Lugg when he was operating in the south of the Colony. 
Hosking was a farmer at Byrne, in the southern part of the Colony. Lugg remained in Natal, and Hosking continued in Zululand as McKenzie's intelligence officer, and appears now and then in reports as "Intelligence McKenzie" and "Intelligence Nkandhla", but no clear picture of him emerges. ${ }^{30}$

There was a succession of units making up the Helpmekaar Field Force, including the Natal Carbineers and the Natal Mounted Rifles, local reserves, and small detachments of infantry at Helpmekaar and Pomeroy. Captain W Wilkinson Rider was the intelligence officer at Helpmekaar, at least by the end of the rebellion. He was also a minister in the Methodist Church. He appears in a few reports, but again, no clear picture emerges. ${ }^{31}$

The commissioner for Native Affairs in Zululand was the government's political agent, and he appointed two Resident Magistrates, Benjamin Colenbrander of Nkandla and Richard Addison of Estcourt, as his Political Agents to accompany the militia and police columns respectively when McKenzie ordered the convergence on Cetshwayo's grave. They had charge of the native levies, raised from loyal chiefdoms, although not tactical control, which was in the hands of European militia officers. They acted as intelligence officers for the commissioner, and they provided much valuable information through their contacts. ${ }^{32}$

Colenbrander, attached to McKenzie's column when it took the rebel base at Cetshwayo's grave. and Addison, attached to Mansel's column, reported directly to Saunders. It cannot be said that they were equally useful. Colenbrander was a civil servant with sixteen years' experience in Zululand, but he had only become magistrate at Nkandla at the beginning of 1905. He was not in good health, nor did he see eye to eye with Saunders, who was at the magistracy until 7 June. Colenbrander went on extended sick leave on 5 June. ${ }^{33}$ Addison had been in the service thirty years and knew Zululand (and Dinuzulu and Mansel) well. He was on friendly terms with Saunders and took leave as magistrate at Estcourt to do this work in Nkandla. He made good use of native police and informants, and his reports are illuminating and often (but not always) insightful. ${ }^{34}$

The sharing of intelligence between the magistrates and the column commanders was expected, but apparently did not happen in southern Natal. ${ }^{35}$ However, it seems to have worked reasonably well in Zululand. Colenbrander was at some disadvantage because of the physical distance between the magistracy and the militia camp, except when he was with the native levies in the expedition to the grave. Addison was always with Mansel's column. Some divergence in perspective and judgement was to be expected, of course, but only once was there a serious disagreement between Saunders and McKenzie, about the threat of a rising in southeast Zululand early in June. It ended with the rebel defeat at Mome. ${ }^{36}$ 


\section{Scouts and spies}

A survey of intelligence's "synopsis of wires received" and of local press reports from the front shows how extensive and variegated field intelligence was in practice. There are many references simply to "information" and "reports" received, even "rumours", and occasionally to "reliable sources", about whose identity the reader can only make conjectures.

Organised reconnaissance was a constant feature of operations and the main empirical source of information, with scouting as an important component. There are many references to militia and police patrols and to native scouts recruited from loyal tribes during the rebellion. Native Scouts had been employed in Natal and Zululand during the South African War. They operated loosely, sometimes individually, and appear to have been mounted. The tribal levies (also called "friendlies" by the militia) were also useful. ${ }^{37}$ Stephenson describes the scouting system in Nkandla:

Behind the advanced Scouts there is usually a body of natives [sic] Scouts close at hand to whom they communicated all they hear, and who pass the information on to white Intelligence agents, who lie hidden at some distance to the rear. ${ }^{38}$

As during the South African War, the locally recruited Scouts provided valuable information, but they could not be expected to distinguish between what was important and what was not. Furthermore, they rarely appreciated the value of negative information, e.g. where the enemy was not. ${ }^{39}$

In McKenzie's first reconnaissance, on 10 May, 100 Native Scouts, most of them mounted, went into the Nsuzi valley, covered by Natal Carbineers, and burnt about twenty kraals. Scouts (the number is not given) are mentioned bringing information about the enemy to the forces at Cetshwayo's grave on 18-21 May, although on 18 May, they at first mistook a mass of women and children for an impi. $^{40}$

A large number of natives were employed in espionage during the early part of the South African War. During the rebellion, loyal chiefs provided much information, but the most important source of information was the enemy community. A spy could get among the people and learn much through conversation and simply listening. There are a fair number of references to spies in the synopses, i.e. secret agents employed by magistrates and militia. All were natives. The police had their "native detectives" and constables, and the magistrates' courts had their izinduna and constables. Colenbrander speaks highly of the work of the brothers Bayekana and Zineke, employed as constables at the Nkandla magistracy. ${ }^{41}$ 
General Stephenson was particularly impressed with the Zululand Mounted Rifles, headquarters Eshowe, 9 officers and 115 men, and with Lieutenant JS Hedges, who knew Zululand well and spoke Zulu fluently. Stephenson thought that he "would make an excellent Head of an Intelligence Department". ${ }^{2}$ McKenzie chose Lieutenant Hedges and Sergeants Calverley and Titlestad of the Zululand Mounted Rifles to get information about the rebels' plans and movements, and he gave them a free hand to do so. Hedges was a government inspector of mines, based in Nkandla. Calverley and Titlestad were local storekeepers who knew the country intimately and had an excellent reputation among the natives. ${ }^{43}$

Refugees from the combat zone would talk, either to those with whom they sought refuge, who would then inform the authorities, or to intelligence operatives. Captured and surrendered members of the rebel impi furthermore provided timely information, especially if they were deserters intercepted on the way home, for then they had little to lose by informing their captors about the conditions when they left. Of course, most of these informants could speak only from their own experience. What they said of things beyond their ken was hearsay and sometimes downright wrong. Furthermore, the rebels were not incapable of disinformation, as suggested in contradictory reports received about Dinuzulu's counsellor Mankulumana's mission to negotiate for Sigananda's surrender. Saunders admitted at one point that it was impossible to obtain reliable information as to Bhambatha's whereabouts. ${ }^{44}$

Women and children posed a special problem. Henderson's Field intelligence called the questioning of women "a very difficult matter" in which a man was always at disadvantage. ${ }^{45}$ During a reconnaissance on 12 May, many kraals were burnt and 100 cattle and many goats were seized, and many women and children came out of hiding. They were moved out of danger and questioned closely, but they absolutely refused to give any information. The same thing happened during the drive of the Mome on 1 June. On that occasion, no one even bothered to interrogate them. They knew that the militia (but not necessarily the levies) would not harm them, and the militia knew they knew, and regarded them as potential spies. $^{46}$

\section{Intelligence at Krantzkop}

Krantzkop was a small village in the highlands fifteen miles east of Greytown. It was the seat of the magisterial division of the same name. According to the census of 1904, the division had 348 Europeans and 671 natives in service, while 20101 natives lived in the location. ${ }^{47}$ 
At the outbreak of the rebellion, the Krantzkop Reserves had pursued the fleeing Bhambatha while Khabela tribesmen did nothing to stop his passing through their location. Until active militia arrived, the reserves secured the village. The native police at the magistracy were mostly Khabela and Ngcolosi, and Captain Gallwey, commanding the squadron of Umvoti Mounted Rifles, which reinforced the reserves, suggested to Leuchars that they be removed. Thus, the native police at Krantzkop were exchanged for those at Estcourt. ${ }^{48}$

The first full report from Intelligence Krantzkop in the synopses is that of 23 April, the last that of 25 June. During this time, the intelligence officer was Captain Landsberg of the Umvoti Mounted Rifles.

Prior to Landsberg's appointment, the local magistrate, AW Leslie, wired daily intelligence, gleaned from scouts and at least one secret agent. During the last week of April and the first week of May, both Leslie and Landsberg wired reports. During the week of 11-18 May, when Leuchars was operating in the valley below Krantzkop, they evidently reported to him, for his reports from the field are comprehensive and detailed. When Leuchars moved upstream to Ngobevu and operated thereafter in the Mfongosi district, Landsberg resumed reporting almost daily, and Leslie seems to have ceased. ${ }^{49}$

In thirty reports, Landsberg mentions scouts bringing in reports or persons in seven instances. He also mentions a patrol to Middle Drift. Some of the persons brought in were refugees. On or about 25 May scouts brought in twenty kraal heads from across the river, whom Landsberg examined and determined had not been part of the rebel impi. ${ }^{50}$ Only once does Landsberg refer to "reliable sources", 51 and often he does not say where he gets his information. Government could not expect informants to put themselves at risk. Both magistrate and intelligence officer stated that scouts gave information in confidence and did not want their identity to become public. $^{52}$

Early in May, the Khabela and Ngcolosi chiefs, evidently taking note of the rebel defeat at Bhobe Ridge and loss of kraals and livestock, decided to give more than nominal support to the government, which made intelligence work easier. Henceforth, river guards watched the crossings and sent in information and captured deserters from the rebel impi, which Landsberg mentions in ten instances. ${ }^{53}$

On 27 May, Landsberg reported on the rebel tendencies of the tribes in the Krantzkop Division, and the commandant referred it to the under-secretary for Native Affairs, who referred it to Leslie, who commented on 26 June. Landsberg and Leslie generally agreed, but Landsberg was more severe in his strictures on the 
chiefs, which the chief staff officer at militia headquarters suggested to the undersecretary was because Landsberg probably had access to more sources. ${ }^{54}$

On 23 April, Landsberg learned from refugees the rebel impi's challenge and password. He also received timely information of a rebel raid in the Eshowe Division on 30 April, and of a projected incursion into Natal on 31 May. On 3 May he found out the name of Dinuzulu's retainer with Bhambatha. In late May and early June, he located the units of the rebel impi in the vicinity of Qudeni. On 20 May, he reported of a prisoner telling that Bhambatha had gone to Dinuzulu and that Sigananda had sent messengers to Dinuzulu reporting the militia's burning of his father's grave. ${ }^{55}$ These examples reflect Intelligence Krantzkop's efficiency, but it should be borne in mind that similar and sometimes identical information was received at other intelligence posts as well. On 18 April, at Empandhleni, Saunders had learnt the rebel challenge and password, five days before Landsberg did. ${ }^{56}$

\section{The crisis of the rebellion in Zululand}

McKenzie took the offensive on 17 May when the Zululand Field Force converged in three columns on the rebel base at Cetshwayo's grave. The government forces captured and burnt the rebel camp, captured much livestock and destroyed stores of supplies, but the impi escaped into the Nkandla forest. Sigananda proposed to surrender. It was a blind, but McKenzie declared a truce to give him time to come in. No one was surprised when he did not. McKenzie left Mansel with a force at the grave, thus further reducing the rebel scope of operations, and returned with the main body to Empandhleni on 23 May. On the night of the 25/26 May, McKenzie

made a daring but fruitless night march to strike an impi reported to be on Qudeni. ${ }^{57}$ On 29 May, under the critical eye of General Stephenson, McKenzie tried to surround the enemy in the Thathe gorge stronghold. He almost succeeded. There were some small, fierce combats and much stock was taken. ${ }^{58}$

Again and again, McKenzie had struck at the enemy, supposing he would stay fixed and fight. He moved secretly, suddenly, speedily. His intelligence was good; but he could never move quickly enough to obtain surprise and the enemy vanished before him. Bru-de-Wold was on the verge of nervous collapse, and the governor, Sir Henry McCallum, intervened. Over Bru-de-Wold's signature he ordered McKenzie to drive the forests methodically. Militia and levies would line up and sweep through a valley. ${ }^{59}$ There was a possibility that the enemy might escape, but his homesteads would be destroyed and his stock taken. Nowhere would he be safe and soon he would starve. He would become demoralised and started to desert. Defectors were a great help to intelligence, as proved in the South African War. ${ }^{60}$ 
There is no question that the loss of Cetshwayo's grave shook the rebels, and their leaders sought assistance from Dinuzulu. He could not give it, but directed them to the important and influential chief Mehlokazulu in the Nqutu Division who rebelled at the time. Mackay's column moved to Nquthu, and Mehlokazulu's impi moved to Qudeni in Nkandla and combined with the rebel forces there. They cleared the area of loyalists, and threatened to invade Natal. ${ }^{61}$

Meanwhile Bru-de-Wold went on sick leave, and McKenzie drove the Nkandla forest, one portion at a time. On 1 June, Bru-de-Wold drove the Mome valley, and burnt Sigananda's chief kraal. On 3 June, he drove the upper reaches of the Mome, and there was a sharp fight at Manzipambana. On 4 June, he swept the upper reaches of the Mavungwini below Susa. On 6 June, he drove the Nkunzana valley, and on 7 June, the Halambu, but he had to halt there because his troops were worn out. No enemy was found, because most of Sigananda's impi had filtered through the forest in pursuit of Manzipambana to join Mehlokazulu. McKenzie decided to go to Qudeni and drive the forests there. ${ }^{62}$ Before he could do so he received intelligence that Mehlokazulu was coming to him.

Sigananda's people had borne the brunt of the war in Nkandla, and late in May demoralisation and desertion increased. It extended to the highest level. On 26 May, one of Sigananda's sons, Mbebeni, surrendered. ${ }^{63}$ The same day, one of Sigananda's izinduna, Mpikwa, passed important information that Sigananda had five companies (three of them Natal rebels) in the Nkandla forest and that another two companies under Ndhlekeza were near the Mfongosi Valley and one large one was in the Nkonjeni forest of Qudeni. ${ }^{64}$

On 28 May, Mpikwa surrendered at the magistracy. Mpikwa was one of Sigananda's oldest izinduna. He governed the section of Sigananda's tribe which lived between Ntingwe and Ofeni. When the Zululand Mounted Rifles occupied Ntingwe at the beginning of May, Mpikwa informed the native caretaker of the store, whose owner, Elias Titlestad, was doing service, that he wished to surrender. Titlestad went to see Mpikwa. Mpikwa's men then went to the camp and gave up their shields, and Major Vanderplank, commander of the Rifles, told them to return to their homes. Perhaps it was about this time that Mpikwa began passing information to intelligence.

Mpikwa refused to join Sigananda's impi, and when Sigananda threatened to attack him, his people went into hiding. But then the militia destroyed the rebel camp at the grave. Some days later, Saunders sent for Mpikwa, who went alone to the magistracy and surrendered on 28 May. Saunders sent him to McKenzie, who gave him a pass to bring his men in. Mpikwa also undertook to bring in Sigananda's brother Mhlola and his section of the tribe. ${ }^{65}$ 
Also on 28 May, Fomoti and Nsingisi, two well-to-do kraal heads of Sigananda's tribe who had remained loyal to the government, came to the magistracy. They brought six of their sons, who had joined the rebels but returned home the night before in order to surrender. The sons were given to serve with levies; the fathers would stand surety for them with their lives and property. It was decided to accept the offer, as an experiment. The very next day, the sons were in action at Thathe. Their conduct was exemplary, then and thereafter. ${ }^{66}$

At midday on 1 June, Mpikwa arrived at the magistracy with Mhlola and seventy-five other men, including two of rank. They all declared they were opposed to Sigananda's conduct and had refrained from participating in the rebellion. Mpikwa said that he had sent a spy to Qudeni the previous day, who went right among the rebels and found that there were fourteen companies. The rebel leaders Mehlokazulu, Mteli and Lubudhlungu were there, and on 31 May had raided the kraals of loyalists in Mbuzo's tribe. Moreover on 30 May, Sigananda had sent four messengers to Qudeni with a message, begging the impi there to join him in the Nkandla forest, but they did not. ${ }^{67}$

On 1 June, when McKenzie drove the Mome, Simoyi, another of Sigananda's izinduna, came out with twenty-four men and surrendered to avoid capture. ${ }^{68}$ On 2 June, six more men surrendered, and it was learnt that Mehlokazulu was in force at the forester's house at Qudeni. ${ }^{69}$

On 8 June, nine more of Sigananda's tribe surrendered at McKenzie's camp. They were sent back into the bush as secret agents to establish where the chief was hiding. ${ }^{70}$ On 9 June, scouts confirmed that Sigananda's impi had left Nkandla, and only a few men remained with the chief. When the impi left, half of the Natal rebels had deserted to go home. ${ }^{71}$ One of the levies, who had been captured by Mehlokazulu's impi and had taken to Qudeni, and had escaped, reported that Sigananda's impi had arrived from Nkandla on 7 June. Small numbers continued to arrive daily. Mehlokazulu's impi had about forty companies in and around the forest, and he intended "to work toward" the Macala and then the Nkandla forests. The men were "full of big talk" that they were strong enough now to take on the government forces. $^{72}$

\section{Intelligence vindicated at home}

By 9 June, McKenzie's intelligence had enough information from scouts and spies to know that the main rebel impi under Mehlokazulu and others was at Qudeni and intended to move to Nkandla. Meanwhile Lieutenant Hedges and Sergeants Calverley and Titlestad had been trying to ascertain Sigananda's whereabouts for 
some time. During the drive on 1 June, every effort was made to find out where Sigananda was, but to no avail. ${ }^{73}$

Calverley knew one of Sigananda's men who had surrendered on 8 June well, and made him a spy. He and Titlestad took the man to the Mome forest that afternoon, and ordered him to go down in the valley and find one Mandisindaba, whom Calverley had known for many years. Mandisindaba's kraal had been burnt, but Mandisindaba was still in the area. Not long afterwards, the man returned with Mandisindaba, his family and his cattle.

Mandisindaba said that he was tired of the rebellion, and appealed to Calverley for protection. They made a bargain: Mandisindaba would go to the Mome at once to locate Sigananda, and Calverley would ask McKenzie (who had already authorised him to do so) for a free pardon for Mandisindaba, providing his information was correct - otherwise he need never hope to see his family or stock again. Mandisindaba readily agreed. He left them to Calverley's care, and descended into the wooded valley, accompanied by two or three native scouts and two spies disguised as messengers from Dinuzulu.

The party went to a place where they thought Sigananda might be, but it was deserted, except for an old woman, who said she did not know where the chief was. They turned back, and Mandisindaba met a man wading through the stream at the bottom of the valley. He was also of Sigananda's tribe, and they exchanged the usual salutations. Mandisindaba said that he had two messengers from "the Prince", with a message for Sigananda. Did he know where Sigananda was? "No," replied the other man, "that is just what I want to know myself, as I have a message for him from Mehlokazulu and Bhambatha to say they are coming with 1000 men tonight to fetch him out."

They travelled on together, and Mandisindaba saw a boy carrying food, going in the direction of a ravine just below the Mome stronghold. He saw one of Sigananda's wives watching the boy approach, and concluded the food was for Sigananda. Mandisindaba was now convinced he knew where Sigananda was. It was getting dark, and he suggested to the other man that they separate and search for Sigananda's refuge. The one who found it would shout to the other. Immediately the man was out of sight Mandisindaba returned to Calverley and Titlestad at the appointed rendezvous. ${ }^{74}$

Calverley and Titlestad hastened to the camp. At about $21 \mathrm{~h} 00$ or $21 \mathrm{~h} 30$, Hedges, Calverley and Titlestad reported to McKenzie - they had located Sigananda in the vicinity of the Mome stronghold. That same day, two native scouts had learnt that Mehlokazulu's and Bhambatha's impi had moved that day from Qudeni and was 
proceeding to the Nkandla forest. "Through the agency of [Colenbrander's induna] Bayekana" this intelligence had been conveyed by special runners to the magistracy. It was late in the afternoon when it was sent to McKenzie at Nomangci. Sometime before $23 \mathrm{~h} 00$, the messenger arrived at headquarters. The message confirmed what Hedges and the others had said. ${ }^{75}$

McKenzie believed that native superstition about the forest at night would cause the impi to halt at the entrance of the Mome and probably enter the wooded gorge at daybreak. He decided to try and cut them off and surround them before they could get in. He quickly made plans, and ordered Colonel Barker, who commanded the column of militia, police and levies encamped near Cetshwayo's grave to move in force at once to the mouth of the Mome valley, to block the entrance and to try and waylay a strong impi reported moving thither from Qudeni. He also had to send Native police and levies up the valley to meet McKenzie's force, which would try to capture Sigananda and drive down the valley. ${ }^{76}$

At 02h00, Barker marched with the bulk of his force from Nkulutshana. Only he, his adjutant, and the guide, Mr Weir, knew their destination. It was about twelve kilometres from the camp to the mouth of the Mome gorge. At 03h30, the advance guard of the column reported seeing the campfires of the impi. Barker halted at once and made dispositions to surround the camp. At 03h00, McKenzie marched with the main column from Nomangci. McKenzie and General Stephenson headed the column. Sergeants Calverley and Titlestad were the guides. At 05h30, the column halted on Dlabe Ridge, and McKenzie disposed units to surround the small Mvalasango forest, where Sigananda was believed to be hiding. ${ }^{77}$ He may not have been there ${ }^{78}$ but in another hour, it would not matter.

Meanwhile the rebel impi, between 1200 and 1500 men, had marched at sunset from Macala hill, about twelve kilometres to the west, as the sun set, and arrived in sections at the mouth of the gorge between $23 \mathrm{~h} 00$ and sometime after midnight. The men, tired and cold, built fires and lay down to sleep, without sentries being posted. Barker was far away. The searchlight at McKenzie's camp was working as usual. Yet, some of the leaders were uneasy; they knew the enemy's penchant for night marches and morning surprises, and in the early hours of the morning they took their men into the gorge. Towards dawn, there was a report of a noise like a wagon, and some others followed. Thus about a third of the impi avoided Barker's trap. ${ }^{79}$

Sunday, 10 June, the sun rose at 0645 and the mist lifted, so that Barker's men could see that the rebels in the camp were forming up. They opened fire, raked the camp for fifteen minutes, and then advanced. The impi broke up in panic. There was a gap in Barker's ring where the Mome flowed from the gorge, and the rebel 
fugitives fled through it until the Native police moved in and sealed it off. McKenzie heard the sound of Barker's fire, and redeployed his units, which drove down the slopes on both sides of the Mome to intercept the impi in the gorge.

McKenzie's and Barker's men met about 07h45, and fugitives were diverted from the Mome into the small forested valley of the Dobo. Barker's guns shelled it, while McKenzie redeployed to drive it. In the afternoon, the troops moved in. There was no escape, but a premature halt just before sunset spared a remnant of the impi in the lower part of the forest. ${ }^{80}$

At last, McKenzie had caught the enemy and made him fight. It was a classic achievement of the objective in terms of Callwell's Small wars, a resounding tactical and strategic victory, even if more of a massacre than a battle. McKenzie estimated the rebel killed at 575. Militia and police lost one killed and eleven wounded (two mortally). ${ }^{81}$ The impi ceased to exist as an organised fighting force. The rebel leader, Mehlokazulu, had been killed in the battle; his body had been found and identified. ${ }^{82}$ Probably Bhambatha had been killed too. A likely body was found a few days later. The head was cut off and served well enough for identification purposes. ${ }^{83}$ Sigananda was ferreted out by Hedges and Calverley and surrendered on 13 June. ${ }^{84}$ There was some mopping up to do, of course, but on 17 June, McKenzie reported that the rebellion in Zululand was practically over. ${ }^{85}$

\section{Conclusion}

It was the purpose of this article to describe militia intelligence (and incidentally, civil intelligence) during the crucial second phase of the Zulu Rebellion. In the course of the narrative, it was shown that the militia had a background and knowledge of military field intelligence based on British army experience in the South African War. The Imperial Military Intelligence Department (South Africa) served as an example for the colonial militia, which did not have a proper intelligence department of its own until the rebellion broke out.

The thesis of the article was that the Zulu Rebellion forced the Natal militia to establish an intelligence department and to improvise a system of field intelligence especially adapted to the circumstances. In the crisis, militia headquarters appointed a chief intelligence officer and put together a structure in keeping with the lessons of the South African War. This has been shown in the department's organisation and activities and some of the achievements of intelligence officers in the field. Experience and circumstances enhanced performance. Yet, field intelligence was never timely enough to enable a column commander to strike the enemy where he was reported to be. The rebels always 
managed to find out in time to avoid the blow. For all this, the militia's imperfect intelligence was vindicated by success at Mome, where the impi, its leaders absorbed in their own mission, was caught and surprised.

The proven value of the intellegince department in operations assured its continued existence after the rebellion. Bru-de-Wold returned to duty on 2 July, and Major RW Wilson continued as intelligence officer. The position became permanent at militia headquarters. ${ }^{86}$ However, there still was no vote in parliament for funding its work. It took several years to set up a network of intelligence agents throughout the Colony, but by the time of Wilson's death in June $1909,{ }^{87}$ the work was done. The agents were officers in all parts of the Colony. They did the intelligence work voluntarily, although it is not clear whether or not their "assistants" did so without some remuneration. Colonel McKenzie, at that time commandant general of the Natal Defence Force, wrote in his report in 1908 that the intelligence system was "sound and comprehensive" and "in thorough working order". 88

\section{Endnotes}

${ }^{1}$ General histories that cover the colonial period are Brookes, EH \& Webb, C de B. A history of Natal. Pietermaritzburg: University of Natal Press, 1965 and Duminy, A \& Guest, B (eds), Natal and Zululand from earliest times to 1910: A new history. Pietermaritzburg: University of Natal Press \& Shuter \& Shooter, 1989. According to the first South African census in 1904, Natal's population was 1108754 to 91109 Europeans, 100918 Indians and Asians, 904041 Natives, and 6686 mixed and others. Colony of Natal. Statistical year book for the year 1904. Pietermaritzburg: Davis, 1905 (hereafter SYB), 11.

2 Thompson, P. "The Natal Militia: Defence of the Colony, 1893-1910". Journal of Natal and Zulu History 29. 2011. 30-45.

${ }^{3}$ In this paper, proper names of persons and places are spelt in accordance with current modern orthography, except that prefixes are omitted, which is common practice; however, proper names of places that were used in 1906 are spelt in accordance with contemporary orthography. Similarly, contemporary terms such as chief, headman, kraal, native and tribe are used without prejudice, as they have exact meanings, described in the Native Code of 1891.

${ }^{4}$ The rebellion and its troubled aftermath are covered by Stuart, J. A history of the Zulu Rebellion and of Dinuzulu's arrest, trial and expatriation. London: Macmillan, 1913, ch. 6-24; Marks, S. Reluctant rebellion: The 1906-1908 disturbances in Natal. Oxford: Clarendon, 1970, ch. 7-13; Guy, J. Remembering the rebellion: The Zulu uprising of 1906. Pietermaritzburg: 
University of KwaZulu-Natal Press, 2006, ch. 4-8; Thompson, PS. An historical atlas of the Zulu Rebellion of 1906. Pietermaritzburg: private, 2001 (hereafter $H A Z R$ ). The second phase is also dealt with in Colenbrander, B. "[A] brief history of the 1906 Native Rebellion" (cited hereafter as Colenbrander's Report), a 36-page typescript attached to his Annual report on the Native population Nkandhla Division for the year 1906 in the Archives of the Secretary for Native Affairs (hereafter cited as SNA), Vol. I/1/414: Minute 3258/1906; these and other archives cited in this article are in the KwaZulu-Natal Archives Depot, Pietermaritzburg Archives Repository (cited hereafter as PAR), unless otherwise stated. See also Thompson, PS. Bambatha at Mpanza: The making of a rebel. Pietermaritzburg: private, 2004 and "Bhambatha and the Zulu Rebellion". Journal of Natal and Zulu history. 26. 2008. 31-58. The third phase is dealt with in Guy, J. The Maphumulo uprising: War, law and ritual in the Zulu Rebellion. Pietermaritzburg: University of KwaZulu-Natal Press, 2005.

${ }^{5}$ Fergusson, TG. British Military Intelligence, 1870-1914: The Development of a Modern Intelligence Organization. Frederick, Md.: University Publications of America, 1984, pp. 181.

${ }^{6}$ This section is based on Fergusson, TG. British Military Intelligence, 1870-1914: The development of a modern intelligence organization. Frederick, MD: University Publications of America, 1984, 139-142, 152-154, 157-162, 167, 173-181; Haswell, J. British Military Intelligence. London: Weidenfeld \& Nicolson, 1973, 62-63, 67-68, 75, 79.

${ }^{7}$ Callwell, CE. Small wars: A tactical textbook for Imperial Soldiers (new ed). London: Greenhill, 1990.

${ }^{8}$ New books in the militia library are given in Militia Orders only for 1906-1908 (see the Natal Government Gazettes for the period, passim).

${ }^{9}$ See Fergusson op. cit., p. 149 and Haswell op. cit., pp. 59-60.

${ }^{10}$ Thompson, "The Natal Militia ..." op. cit., pp. 32-45.

${ }^{11}$ Colony of Natal. The Natal Government Gazette (hereafter NGG). 3635A (1 October 1907), Supplement No. 17; Government Notice No. 561, 1907: Annual Report by Commandant of Militia for 1906 (hereafter Commandant's Report 1906), 1036. Archives of the Colonial Secretary's Office (hereafter CSO), Vol. 2599: Minute C147/1906, Interim report by Commandant of Militia Natal on the Native rebellion, 1906 (hereafter Commandant's Interim Report). The Natal Directory. Almanac and yearly register 1906. Pietermaritzburg: Davis, 1905, 190, identifies Wilson, but Colony of Natal. Natal Civil Service List 1906. Pietermaritzburg: Davis, 
1905 (hereafter NCSL), 80, does not. There is no Militia Order establishing the department.

${ }^{12}$ Stephenson, TE "Notes on the Zululand Field Force, May \& June, 1906", in the Archives of the Lieutenant Governor and Governor of the Colony of Natal ("Government House" -- cited hereafter as GH), 569: G585/1906. (Cited hereafter as Stephenson's Report.)

${ }^{13}$ Marks op. cit., p. 150. SNA I//4/8: C187/1900, Under Secretary's memo, and SNA to USNA, 6 June 1900. See subsequent files in this series (Confidential Minutes), passim, for the reports of Native Intelligence Officers.

${ }^{14}$ During the South African War, the CID worked closely with the military. Holt, HP. The Mounted Police of Natal. London: Murray, 1913, 251-254, 263264. Clarke, WJ. My career in South Africa (2 vols., typescript in PAR), I, 86-93.

${ }^{15}$ Commandant's Report 1906 op. cit., p. 1036.

${ }^{16}$ Ibid.; NGG 3515 (23 January 1906), 104: MO 23/1906 (23 January 1906).

${ }^{17}$ See $N G G$ 3520, 2522 and 3530 (26 February - 17 April 1906), Militia Orders nos. 63, 63 and 92; also PM 102: C230/1906, Wales to PM, 6 May 1906. The following account of militia intelligence is based on archival material.

18 Commandant's Report 1906 op. cit., p. 1036. CSO 2599: C147/1906, Report of the Chief Intelligence Officer, Natal. See Archives of the Prime Minister (hereafter PM) 101: C88/1906, copies of telegrams from Intelligence, 21 February - 25 March 1906; and SNA I/4/16: C123/1906 and C137/1906, transcripts of meetings with various chiefs and izinduna 1-5, 12 March and 5 June 1906; C136/1906, extract of letter, 3 March 1906; and C168/1906, letter 14 March and report 14 May 1906.

19 Archives of the Lieutenant-Governor and Governor of the Colony of Natal (“Government House" - hereafter GH) 526, 1-14; 549, 81-104; 552, 97105. Copies were sent to Natal, and ones for the period May-December 1900 are in the Government House archives.

${ }^{20}$ See PM 101: C88/ 1906 and 102: C230/1906; and GH 1465-1466 passim.

${ }^{21}$ Colenbrander's Report; Stuart op. cit., pp. 183, 187, 194-197, 202-203, 213-216. Thompson, "Bhambatha and the Zulu Rebellion" op. cit., pp. 11-16. Perrett, IM. "Dinuzulu and the Bambata Rebellion". MA thesis. University of Natal, 1960.

22 Commandant's Interim Report 1906. Stuart op. cit., pp. 189-190, 194-195, 203, 211-212, 215-219, 222-231, 237-267; Colenbrander's Report; Thompson, “The Natal Militia ...” op. cit., pp. 46-48; Thompson, HAZR op. cit., pp. $18-22$. 
${ }^{23}$ See Natal Defence Records (hereafter NDR) 5/3: V1059/6, [WA] J. Burt i/c Field Pay Bd to Paymaster, Militia, 18 August 1906: "Lists of Europeans and Natives Employed by Intelligence Dept." and Cdt. to Min. of Justice, 5 September 1906. Officers employed in intelligence work received the pay of their rank; however, there were discrepancies in pay for similar work to noncommissioned officers and civilians.

${ }^{24}$ Stephenson's Report.

${ }^{25}$ Webb, C de B \& Wright, JB (eds.). The James Stuart Archive of recorded oral evidence relating to the history of the Zulu and neighbouring peoples, 5 vols. Pietermaritzburg: University of Natal Press, 1976-2001.

${ }^{26}$ On Stuart's career, see NCSL 1909, 232, and Natal Directory, 191. CSO 2599: C147/1906, "Diary of field operations during the Native Rebellion of 1906. Umvoti Field Force - Natal" (hereafter UFF Diary). On his ride from Greytown to Empandhleni, see Stuart op. cit., p. 258; UFF Diary; Colenbrander's Report. On his career with Mackay in Nquthu, see Stuart $o p$. cit., pp. 276-278; and CSO 2599: C147/1906, "Report of the doings of Mackay's Column during the late rebellion". Saunders wrote to JC Hignett, the magistrate at Nquthu, in mid-June: "I saw a good deal of James Stuart, and quite agree with your opinion about him. I found exactly the same in all I had to do with him at Nkandhla; as you say, he is a good chap, but I think this business is a little beyond him”. Archives of Resident Commissioner and Chief Magistrate, Zululand (hereafter ZA) 28: CNA to Mgt Nqutu, 14 June 1906.

${ }^{27}$ UFF Diary.

${ }^{28}$ Natal Directory 1903, "Postal Directory", 30.

${ }^{29}$ SNA I/1/342: 1684/1906, CIO, UFF to Commandant, 27 May 1906; UFF Diary. Stuart (op. cit., p. 258) says that Landsberg's information was "remarkably full and accurate".

30 Archives of the CSO, Vol. 2599: Minute C147/1906: "Report of Colonel Sir Duncan McKenzie, September 1906" (cited hereafter as McKenzie's Report) and "Report. McKenzie's Field Force" for 10 February - 30 March 1906. Bosman, W. The Natal Rebellion of 1906. London: Longmans, Green, 1907, 86.

31 SNA I/1/346: 2494/1906: Rider to OC Helpmekaar Field Force, 20 July 1906. 414: 3233/1908: Reply of Mgt Umsinga to SNA Circular 11/1906, 31 July 1906.

${ }^{32}$ Colenbrander's Report; Bosman op. cit., p. 47; Colony of Natal. The Natal Native Rebellion as told in Official Despatches from January $1^{\text {st }}$ to June $23^{\text {rd }}, 1906$. Pietermaritzburg: Davis, 1906, 134: CNA to PM, 26 May 1906 (hereafter 
cited as $O D$ ) (it also appears in the $N G G$ 3568A (2 October 1906)), Supplement No. 16: Govt. Notice No. 592/1906 (2 October 1906), "Correspondence relating to Native disturbances in Natal".

${ }^{33}$ Colenbrander's Report; Archives of the Registrars of the Supreme Court (hereafter RSC) III/3 Special Court: Zulu Rebellion, vols. 2-6: Case no. 3, Rex v Dinuzulu: 5: 3452, evidence of B Colenbrander; $O D$ 138-141, Colenbrander to CNA, 26 May 1906. PM 60; 656/1906, CNA to PM, 5 June 1906.

${ }^{34}$ ZA 34: CNA to PM, 25 July 1906; $O D$ 134: CNA to PM, 26 May 1906; Bosman op. cit., p. 45.

${ }^{35}$ McKenzie was scathing, in his report of operations in the south, on the unfitness of the magistrates and the failure of Native Affairs to impart any information, and urged that "a properly organised Intelligence Department" be set up to do what manifestly they could not. CSO 2599: C147/1906, . "Report of the state of unrest amongst Native population.".

${ }^{36}$ See $O D$ 145, 159, 161, 166-169, 183, 186-187; Stuart op. cit., 203, 339-340, 347-348, 359n; Bosman op. cit., p. 160; Thompson, PS. "Dinizulu and Bhambatha: An invasion of Natal and an uprising in Zululand that almost took place". Historia 56/2. 2013. 53-54, 63.

${ }^{37}$ See Laband, J \& Thompson, P. "African levies in Natal and Zululand, 18381906". In Miller, S (ed), Soldiers and settlers in Africa, 1850-1918, Leiden: Brill, 2009, 74-84; Thompson, PS. "Crossroads of war: The people of Nkandla in the Zulu Rebellion of 1906". Scientia Militaria 35/2. 2007. 9, 95-124 passim.

${ }^{38}$ Stephenson's Report op. cit.

${ }^{39}$ Haswell op. cit., p. 62.

${ }^{40}$ Bosman op. cit., pp. 36, 44, 46, 49. An impi is a body of men armed to fight.

${ }^{41}$ Colenbrander's Report; Cf. GH 1466, 62: Synopsis 7/8 June 1906, report of Intelligence ZFF, Nkandhla; Cf. Mercury 27 Apr. 1906: "McKenzie Takes Command".

${ }^{42}$ Stephenson's Report.

${ }^{43}$ Bosman op. cit., pp. 78, 171; RSC III/3/5: 3516, Colenbrander; Stuart op. cit., p. 414; NCSL 1906, 215.

${ }^{44}$ OD 162, CNA to PM, 1 June 1906.

${ }^{45}$ Fergusson op. cit., pp. 160, 175.

${ }^{46}$ Bosman op. cit., pp. 38, 44, 67-68; Stuart op. cit., pp. 239, 244.

${ }^{47}$ SYB 1904, pp. 14-15.

${ }^{48}$ SNA I/1/414: 3263/1908, "Report of the Magistrate Krantzkop Division, Under Circular 11 SNA 1906".

${ }^{49}$ See PM 102: C230, 1906 and GH 1465, 72-152, Synopses passim. 
${ }^{50}$ See reports of Intelligence Krantzkop in GH 1465: 117, Synopsis 29/30 April; 125, Synopsis 3/4 May; 134, Synopsis 7/8 May; 152: Synopsis 18/19 May; 1466; 10-11, Synopsis 25/26 May; 37, Synopsis 31 May/1 June; 84, Synopsis 12/13 June; 85, Synopsis 14/15 June; 87, Synopsis 14/15 June 1906.

${ }^{51}$ GH 1465: 117, Synopsis 29/30 April 1906.

52 SNA I/1/342: 1684/1906, V5978/6, CIO Krantzkop to Cdt 27 May 1906, and Mgt Krantzkop to SNA June 261906.

53 GH 1465: 154, Synopsis 20/21 May; 1466, 2-3, Synopsis 23/24 May; 12: Synopsis 26/27 May; 32-33, Synopsis 30/21 May; 37-38, Synopsis 31 May/1 June; 75, Synopsis 10/11 June; 85, Synopsis 13/14 June; 94, Synopsis 15/16 June; 101, Synopsis 17/18 June 1906. PM 102: C230/1906, Synopsis 18/19 and 21/22 June 1906; "Native Rebellion. Krantzkop News". Mercury. 25 May 1906.

${ }^{54}$ See reports and correspondence in SNA I/1/342: 1684/1906.

${ }^{55}$ See the synopses with appropriate dates in GH 1465 and 1466.

${ }^{56}$ GH 1465: 13, Synopsis 18/19 April 1906.

${ }^{57}$ Bosman op. cit., pp. 35-55; Stuart op. cit., pp. 237-251, 263-264; Colenbrander's Report; McKenzie's Report.

${ }^{58}$ Bosman op. cit., pp. 60-64; Stuart op. cit., pp. 251-255; McKenzie's Report.

${ }^{59}$ OD 123-124: Gov. to Secretary of State, 1 June 1906; 129, Cdt to OC ZFF, 28 May 1906.

60 Fergusson op. cit., p. 161; OD 134: CNA to PM, 26 May 1906; "Native Rebellion”. Mercury. 6 June 1906; "Native Rebellion: Preparing for work". Mercury. 8 June 1906.

${ }^{61}$ Thompson, "Dinizulu and Bhambatha ..." op. cit., pp. 45-49; Cf. Colony of Natal. The trial of Dinuzulu on charges of high treason at Greytown, Natal, 190809. Pietermaritzburg: Times, 1910, viii-ix, xiv-xv, 31-34, 53-54,74, 81; Stuart op. cit., pp. 513-514; Marks op. cit., pp. 216-217, 285-287.

${ }^{62}$ Bosman op. cit., pp. 65-77; Stuart op. cit., pp. 257-295; McKenzie's Report; CSO 2599: C147/1906, Report of Col. JR Royston, October 1906 (hereafter Royston's Report). Thompson, HAZR op. cit., pp. 28-35; Thompson, "Bhambatha and the Zulu Rebellion" op. cit., pp. 21-23.

${ }^{63}$ Colenbrander's Report.

${ }^{64}$ GH 1466: 12, Synopsis 26/27 May 12906, report of OC ZFF.

${ }^{65}$ OD 141: CNA to PM 29 May 1906; 161-162: CNA to PM, 1 June 1906; PM 102: C228/1906, CNA to PM 28 May 1906. Stuart op. cit., p. 284; "Developments to date". Natal Witness. 2 June 1906: ZA 34: R25/1907, R v Tulwana: Mcetshwa; Mpikwa in $\mathrm{R} v$ Sigananda, R v Ndabaningi, R v 
Jikajika et al. (SNA I/6/26: GH285/1906). R v Mjado et al. (1/NKA 1/5/1/1, No. 7); also his precognition in Colenso Collection 111, and statement 9 December 1908 in AGO I/7/55; Elias Titlestad in R v Mjado et al. and R v Nombika (SNA I/6/27: GH289/1906); Colenbrander's Report; R v Jikajika et al. and R v Nombika et al.

66 Colenbrander's Report. They were also conspicuous in killing their former comrades at Mome on 10 June, and after the rebellion they were pardoned

${ }^{67} \mathrm{GH}$ 1466, 37: Synopsis 31 May/1 June, report of CNA.

68 "Native Rebellion: More fighting". Mercury. 2 June 1906.

${ }^{69} \mathrm{GH}$ 1466: 42, Synopsis 1/2 June 1906, reports of OC ZFF.

${ }^{70}$ Ibid.; 66, Synopsis 8/9 June 1906, report of Intelligence Nkandhla.

${ }^{71}$ Ibid; , report of Intelligence Col. McKenzie.

72 McKenzie's Report; Stuart op. cit., p. 295; GH 1466: 42, Synopsis 1/2 June, report of OC ZFF; 50, Synopsis 4/5 June, report of OC ZFF Nkandhla; 53, Synopsis 5/6 June, report of Intelligence Nkandhla; 66, Synopsis 8/9 June 1906, report of Intelligence Col McKenzie; "Native Rebellion: Mansell's casualties". Mercury. 4 June 1906; "Native Rebellion: McKenzie's drives". Mercury. 8 June 1906; "Native Rebellion: Field force resting”. Mercury. 9 June 1906:

73 McKenzie's Report. According to a newspaper report a few days later, he was hiding just a short distance away. The drive on the $6^{\text {th }}$ went through a forest where he was supposed to be hiding, but he was not found ("Preparing for work". Mercury. 8 June 1906).

74 Stephenson's Report; Bosman op. cit., pp. 78-80; Stuart op. cit., pp. 296-297. These accounts differ in details, but are not incompatible; however, some of Stuart's additions are omitted here.

75 Stuart, Zulu Rebellion, p. 297; Cf. Bosman op. cit., p. 82, which dismisses the intelligence with a single sentence, and Colenbrander's Report, with a paragraph; however, his information is second-hand.

${ }^{76}$ Quoted in the McKenzie's Report and Bosman op. cit., p. 81 and Stuart op. cit., pp. 297-298.

77 Bosman op. cit., pp. 83-84, 88-89; McKenzie's Report; Powell, WJ. The Zulu Rebellion of 1906: A souvenir of the Transvaal Mounted Rifles. Johannesburg: Transvaal Leader, 1906, 45; Campbell, E. The life of Samuel Campbell, told in verse and letter by his daughter (A story of Natal). Durban: private, 1933, 268.

${ }^{78}$ Stuart op. cit., p. 310. 
${ }^{79}$ Ibid., pp. 315-316; in conjunction see the statement of Nsuze in Webb \& Wright op. cit., pp. 162-164; Colenbrander's Report; Thompson, "Dinizulu and Bhambatha ..." op. cit., pp. 59-63.

${ }^{80}$ Stuart, Zulu Rebellion, pp. 299-311, 317; Bosman op. cit., pp. 83-92; Powell op. cit., pp. 45-49; McKenzie's Report; Stephenson's Report.

${ }^{81}$ McKenzie's Report; OD 188: OC Troops Nkandhla to Commandant, 10 and 12 June 1906; Bosman op. cit., pp. 92-93; Stuart op. cit., pp. 311-312.

82 OD 188: OC Troops Nkandhla to Commandant, 10 June 1906; Bosman op. cit., p. 87.

${ }^{83}$ Bosman op. cit., pp. 106-108; Stuart op. cit., pp. 336-368; Also see Thompson, PS. "Bambatha after Mome: Dead or alive?" Historia. 30/1. May 2005. 2348.

${ }^{84}$ McKenzie's Report; Bosman op. cit., pp. 102-104; Stuart op. cit., pp. 335-336.

${ }^{85}$ McKenzie's Report; Bosman op. cit., p. 106; Stuart op. cit., p. 338.

${ }^{86}$ Commandant's Report 1906, 1036; Natal Directory 1906, 190.

${ }^{87}$ NGG 3763 (22 June 1909) 592: Militia Order 98 (22 June 1909): Obituary.

${ }^{88}$ Colony of Natal. Annual report of the Commandant-General, Natal Colonial Forces, for the year 1908. Natal Colonial Publications NCP 8/2/9, in PAR, 6. 